УДК 656.072 .132

DOI https://doi.org/10.32838/TNU-2663-5941/2020.3-2/24

Симонов C.I.

Східноукраїнський національний університет імені Володимира Даля

Соловйов Г.I.

Східноукраїнський національний університет імені Володимира Даля

Усліста В.A.

Східноукраїнський національний університет імені Володимира Даля

\title{
Лищенко О.П.
}

Східноукраїнський національний університет імені Володимира Даля

\section{ПОКРАЩЕННЯ КОЛОРИСТИКИ МІСЬКИХ БУДИНКІВ НА ПРИКЛАДІ ВУЛИЦІ ПРОСПЕКТ ГВАРДІЙСЬКИЙ У МІСТІ СЕВЕРОДОНЕЦЬК}

У статті зроблено постановку проблеми в загальному вигляді стосовно того, щзо для більшості міст пострадянського простору характерна типова забудова житлових кварталів, фасади будинків яких не вирізнялися вишуканістю в плані кольорів. Також відзначено, щзо для індустріальних міст Донбасу характерна сірість фасадів, які, зношені з часом, спричиняють зневіру й депресію в жителів міста, особливо в осінньо-зимовий період, значно знижуючи фізичну активність людини. Зроблено аналіз останніх досліджень і публікацій, для того щцоб дати визначення терміна «колористика», визначити проблему колірної гармонії міст, визначити важливість кольору в архітектурі й будівництві та впливу різних колірних відтінків на людину. Була сформульована основа циіль статі, а саме проведення візуального дослідження й аналіз ситуації з колірною гамою в Сєвєродонецьку на прикладі вулиці проспект Гвардійський, яка є иентральною й найбільщою вулищею иього міста, щяо тепер є столищею Луганської області. Також у статті було зроблено візуальне дослідження колористичного середовища проспекту Гвардійський міста Сєвєродонещьк, виявлено різні проблеми, також наведено результати аналізу колірної гами зазначеного проспекту. Після того як було розглянуто сучасну ситуацію з колірною гамою на цьому проспекті, були виділені актуальні проблеми й запропоновані різні актуальні рекомендаиї для покращення колористики міста. Був зроблений висновок, що в Сєвєродонещьку не приділяється належна увага зовнішньому вигляду міста, і вулиці міста, навіть иеентральні, у досить занедбаному стані. Для того щзоб розв'язати проблему гармонізації та впорядкування колористичного вирішення проспекту Гвардійський, необхідно створити сприятливу, гармонійну обстановку в місті для поліпшення якості життя городян. Актуальність статті полягає в тому, що сучасні проблеми загальної урбанізаиї впливають на зміну візуального середовища, що своєю чергою суперечить можливостям зору людини й формуванню комфортного простору життєдіяльності.

Ключові слова: колористична гармонія, колір, міське середовище, інтегрування, сприйняття кольорів.

Постановка проблеми. Колір відіграє дуже важливу роль у сприйнятті людиною міського середовища. Для більшості міст пострадянського простору характерна типова забудова житлових кварталів, фасади будинків яких не вирізнялися вишуканістю в колірному плані. Для індустріальних міст Донбасу характерна створена індустріальними методами монохромна архітектура, що обумовлює сірість фасадів житлових будинків, які, занепавши $з$ часом, спричиняють зневіру й депресію в жителів міста, особливо в осінньозимовий період, що значно знижує їхню фізичну активність. Незважаючи на те що Сєвєродонецьк - відносно молоде місто, оскільки основна його забудова велася у 1960-80 рр., зараз він має ті ж самі проблеми, що й інші міста Донбасу та більшість міст України, де переважно для фарбування фасадів будинків застосовують асфальтносірий, темно-сірий і синьо-сірий кольори й такого ж кольору утеплювачі для утеплення квартир. В результаті й без того непоказні фасади з часом старіють, стають непривітними, мають похмурий вигляд. Зазначимо, що колір будівель також впливає на рівень освітленості вулиць: чим менша ширина вулиць і більша поверховість забудови, тим більший цей вплив, що позначається на емоційно-образній характеристиці забудови. Вулиці, заповнені сірими фасадами будівель, за низького 
рівня освітленості видаються тьмяними й смутними, а використання жовтих і білих кольорів в оформленні фасадів надають їм «сонячності» навіть у похмурі дні.

Аналіз останніх досліджень і публікацій. Для початку дамо визначення терміна «колористика». Колористика - наука про колір, що охоплює знання про природу кольору, основних, складених і додаткових кольорів, про основні характеристики кольору, колірні контрасти, змішані кольори й колірні гармонії, колірну мову й колірну культуру $[1$, с. 5$]$.

Питання колірної гармонії міст уже порушили в Дніпрі, де вважають, що XXI століття - час інновацій і прогресу, але попри це урбанізація чинить i негативний вплив: з'являються об'єкти містобудування, які не завжди гармонійні та співмасштабні один одному, колористично не пов'язані з елементами навколишнього середовища, внаслідок чого колірний образ міста формується безладно. Водночас руйнується цілісність його сприйняття, 3'являється певна роздрібненість в архітектоніці міського середовища. На сьогодні відсутній комплексний погляд на проблеми, пов'язані 3 колористичною гармонією міського середовища. Саме питанню колористики будівлі слід приділяти першочергову увагу під час вирішення оформлення іiі зовнішнього вигляду, адже саме методи й засоби колористики сприяють чіткому й скоординованому проєктуванню міського середовища [2, с. 15]. Питання колористики порушили в різних містах пострадянських країн, наприклад у Волгограді, де відзначили, що колір фасаду будівлі грає дуже важливу роль в сприйнятті людиною навколишнього архітектурного середовища. Завдяки кольорам можна підкреслити ідею й функціональне призначення будь-якої будівлі, iї форму [3, с. 202].

Важливість кольору в архітектурі будівель неодноразово відзначалася діячами науки й мистецтва. Колір є одним із потужних чинників, що формують комфортне візуальне середовище, й однією 3 найважливіших характеристик більшої частини творів мистецтва. Сучасними вченими-психологами встановлено факт прямого впливу кольору на психологічний стан людини, іiі самопочуття, працездатність і активність, а також вегетативну нервову систему, яка відповідає за діяльність внутрішніх органів. Крім того, завдяки використанню широкої колірної гами можна збагатити візуальне середовище та сповнити його зоровими елементами й потрібною інформацією [4, с. 27].

Слід зазначити, що колір завжди впливав на людину, адже людина живе у світі кольорів і сприймає цей світ за допомогою кольору. Одні кольори приваблюють, збуджують, активізують нас; інші, навпаки, заспокоюють, гальмують. Завдяки правильному використанню кольору в повсякденному житті можна домогтися успіху, підвищити працездатність, змінити настрій.

Шляхом багаторічних життєвих спостережень і спеціальних досліджень психологів і фізіологів було встановлено, як ті чи інші кольори, колірні відтінки впливають на людину. Червоний колір збудливий, активний, він підвищує кров'яний тиск, прискорює ритм дихання, активізує всі функції організму, на короткий час збільшує м'язову напругу. Червоний колір традиційно пов'язується зі святами й веселощами. Але зловживати червоним кольором не варто, він може спричинити роздратування й виснаження нервової системи. Помаранчевий колір тонізує, привертає увагу, тому його часто використовують у рекламі. М'які відтінки помаранчевого кольору сприятливо впливають на працездатність. Жовтий колір оцінюють як колір товариськості й веселощів, він найменше втомлює, є фізіологічно оптимальним, стимулює зір, сприятливий для розумової діяльності. Зелений колір заспокоює й полегшує стан у разі невралгії й мігрені, знижує кров'яний тиск, на тривалий час підвищує рухово-мускульну працездатність. Блакитний колір заспокоює, знижує м'язове напруження та кров'яний тиск, уповільнює ритм дихання, освіжає, знижує апетит, позитивно впливає на здоров'я людини. Встановлено, що у випадку тривалої одноманітної роботи блакитний колір підвищує працездатність. Синій колір сприяє гальмуванню функцій фізіологічних систем людини. За тривалого впливу синього кольору фаза заспокоєння може перейти у фазу гноблення. Фіолетовий колір негативно діє на нервову систему, він часто сприймається як важкий, таємничий. У деяких культурах цей колір символізує мудрість, зрілість, вищий розум. Тривалий вплив фіолетового кольору може викликати меланхолію. Білий колір зазвичай асоціюється 3 чистотою, неміцністю, новизною, спокоєм і невинністю, але у випадку надлишку білого створюється відчуття стерильності, лікарняної атмосфери. Сірий - класичний нейтральний колір, помірно консервативний, традиційний і говорить про інтелігентність. Сірий колір може видатися старим, нудним і нецікавим. Але в поєднанні з іншими нейтральними або яскравими кольорами сірий виглядає сильним, енергійним, вишуканим i красивим. Чорний колір традиційно асоціюється 3 елегантністю, вишуканістю. Він може сприйматися як колір ночі та смерті, чорної магії, неза- 
конних дій (чорний ринок), знедоленої людини (чорний список). Через свою практичність часто використовується в одязі [5, с. 25].

Постановка завдання. Основною метою статті $є$ дослідження й аналіз ситуації з колірною гамою житлових будинків Сєвєродонецька на прикладі вулиці проспект Гвардійський, розгляд наявних проблем і визначення рекомендацій для ïx вирішення. Проспект Гвардійський був обраний як центральна й найбільша вулиця міста, яке тепер є центром Луганської області.

Виклад основного матеріалу дослідження. Розглянемо ситуацію $з$ колірною гамою житлових будинків на найдовшій вулиці Сєвєродонецька проспекті Гвардійському.

У процесі візуального дослідження колористичного середовища житлових будинків на проспекті Гвардійському міста Сєвєродонецька були виявлені такі проблеми:

- відсутність цілісної колірної гармонії;

- відсутність колірних контактів 3 природним оточенням;

- фасади будівель поступово втрачають колірну палітру, тим самим руйнуючи міський пейзаж;

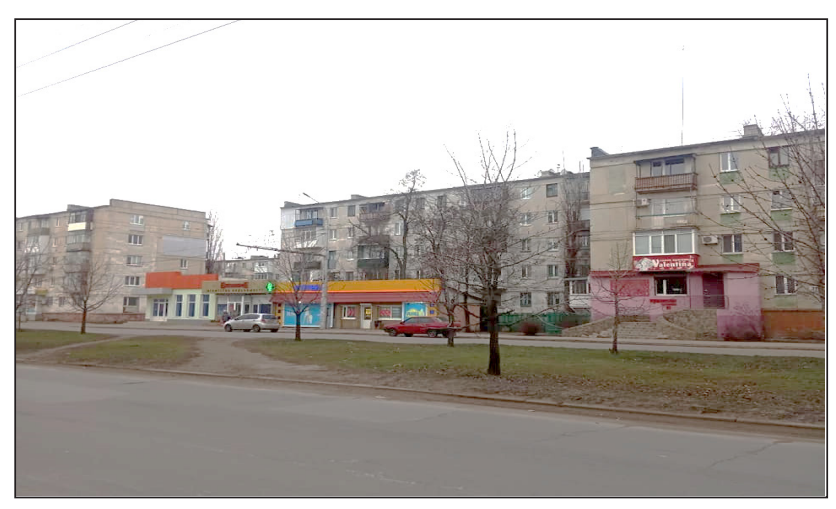

Рис. 1. Проспект Гвардійський

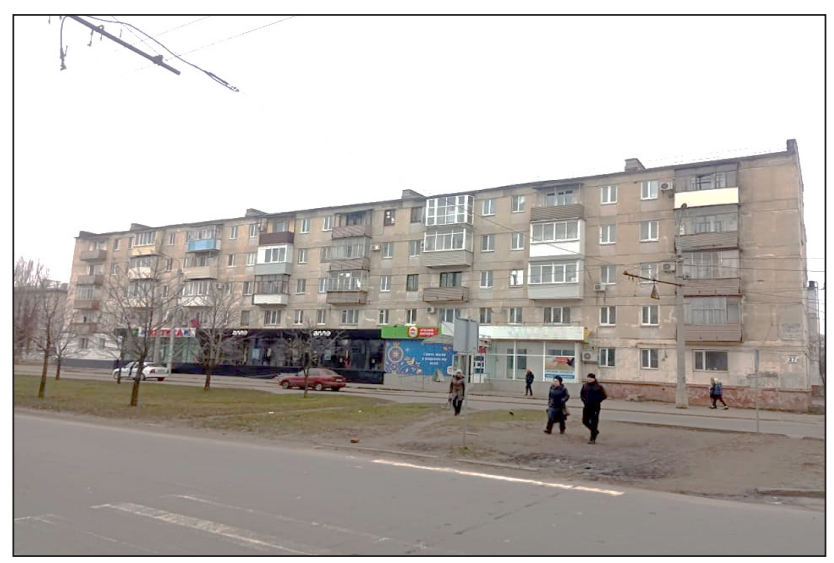

Рис. 3. Проспект Гвардійський
- хаотичне розміщення зовнішньої реклами та вивісок;

- малі архітектурні форми не гармоніюють 3 колірною гамою фасадів будівель.

Все це заважає об'єктивному сприйняттю кольорової гами вулиці міста, що відбивається на психоемоційному стані його жителів, а також створює неправильне сприйняття колірної єдності в архітектурі. Щоб уникнути колірного нагромадження, естетичного безладу, вибір кольору повинен грунтуватися на принципах колористичної гармонії, яка включає в себе розділ знань про колірну культуру й колірні переваги.

Можна зробити кілька рекомендацій щодо поліпшення колірної палітри житлових будинків на проспекті Гвардійському, для чого потрібно:

- зважати на закони колірної гармонії;

- під час створення колористичної карти застосовувати принцип «від загального до конкретного»;

- привести фасади будівель до єдиної кольорової гами;

- створити єдиний стиль для малих архітектурних форм, які гармонійно зливатимуться 3 колірною гамою фасадів будівель;

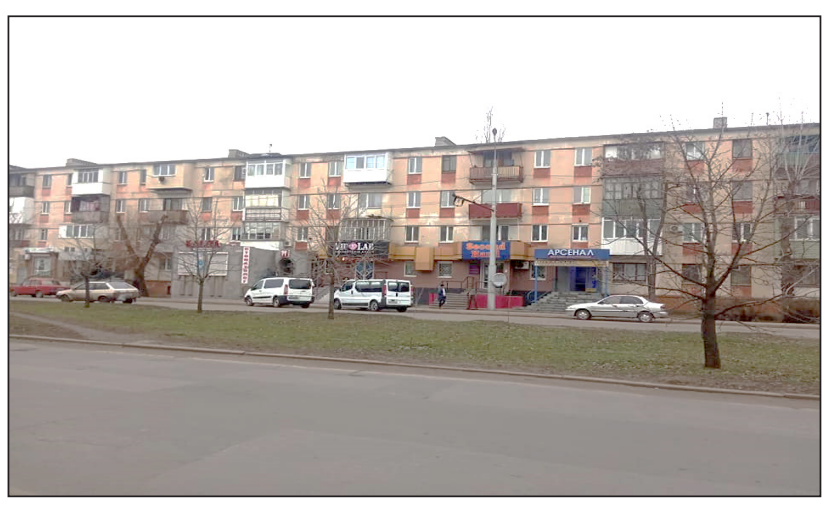

Рис. 2. Проспект Гвардійський

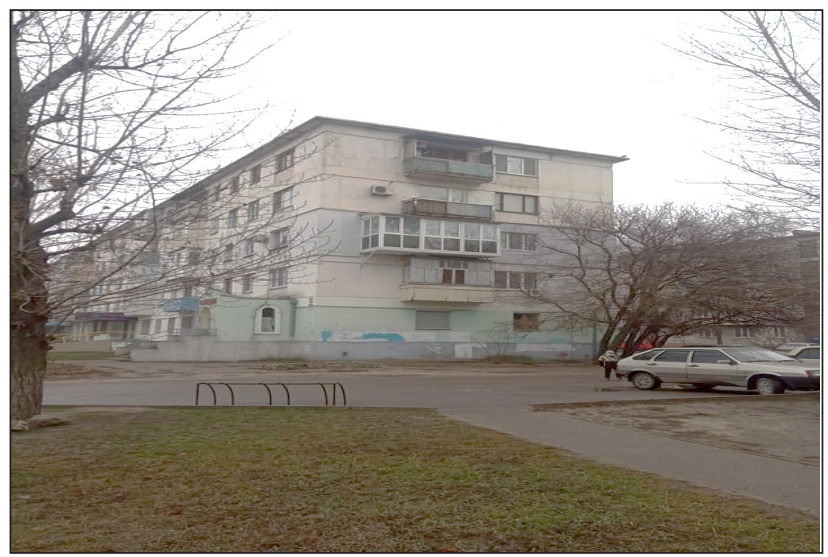

Рис. 4. Проспект Гвардійський 
- використовувати досвід минулого, примножуючи культурне багатство Сєвєродонецька;

- застосовувати місцеві матеріали, віддаючи перевагу відтінкам, які гармоніюють 3 навколишнім середовищем;

- враховувати побажання й переваги жителів міста, для чого проводити опитування;

- необхідно законодавчо врегулювати хаотичне утеплення квартир, щоб вони не псували зовнішній вигляд міста і гармоніювали з фасадом будівлі;

- необхідно не допускати хаотичне розташування й величезну кількість реклами в центральній частині міста;

- подумати про введення нових колоритів, щоб освіжити міський пейзаж.

Висновки. 3 вищесказаного можна зробити висновок, що в Сєвєродонецьку не приділяється належна увага зовнішньому вигляду міста. Вулиці міста, навіть центральні, у досить занедбаному стані, утеплення квартир відбувається хаотично, повністю руйнуючи кольорову гаму житлового будинку та міста. Занедбаний вигляд будівель в центральній частині міста не викликає довіри в потенційних інвесторів, не приваблює в місто туристів. Також однією 3 проблем $є$ те, що до теперішнього моменту колористичне середовище Сєвєродонецька та інших українських міст набуло хаотичного характеру завдяки безсистемному зведенню рекламних конструкцій та об'єктів торгівлі.

Для того щоб розв’язати проблему гармонізації й упорядкування колористичного вирішення проспекту Гвардійського й інших вулиць міста, необхідно створити сприятливу, гармонійну обстановку в місті для поліпшення якості життя городян. Кольори будівель повинні викликати позитивні емоції й утворювати єдину колірну рівновагу, а не діяти розрізнено, викликаючи зневіру й депресію. Колір активно й багатопланово бере участь в нашому житті й чинить сильний вплив на свого глядача, тому необхідно грамотно його використовувати у своїй творчій діяльності для підвищення художньої цінності архітектурного вигляду міста в цілому й так само для підвищення фізичного та психічного здоров' я його мешканців.

Таким чином, розуміння проблеми колористики житлових будинків сучасних міст і, як наслідок, формування рекомендацій щодо вирішення цієї проблеми - актуальне завдання на сьогодні.

\section{Список літератури:}

1. Сфімов А. Колористика міста. Москва : Стройиздат, 1990.272 с.

2. Герцман Е.А., Саньков П.М. Колірна гармонія міста як проблема містобудування (на прикладі центру міста Дніпропетровська). Студентський науковий форум - 2016 : матеріали VIII Міжнародної студентської електронної конференції [Електронний ресурс] URL: https://scienceforum.ru/2016/article/2016022787 (дата звернення 22.11.2019).

3. Иванова Н.В., Минаева К.В., Минаева А.М. Формирование цвето-композиционных решений жилых домов города Волгограда. Международный журнал гуманитарных и естественных наук. 2018. № 5-1. URL: $\quad$ https://cyberleninka.ru/article/n/formirovanie-tsveto-kompozitsionnyh-resheniy-zhilyh-domov-gorodavolgograda (дата обращения: 19.03.2020).

4. Педхем, Ч. Сприйняття Світу і Кольори / Ч. Педхем, Ж. Сондерс. Москва : Наука, 1978. 272 с.

5. М. Купер, А. Метьюз. Мова кольору. Москва : Ексмо, 2002. 114 с.

\section{Simonov S.I., Solovyov G.I., Yslista V.A., Lischenko O.P. IMPROVEMENT OF COLORISTIC URBAN HOUSES ON THE EXAMPLE OF THE PROSPECT OF THE GVARDEYSKI OF SEVERODONETSK}

This article deals with the problem in general, that most cities in the post-Soviet space are characterized by typical residential areas, the facades of which did not differ in any refinement in color, and that the industrial cities of Donbas look similar with gray facades, which decayed over time, cause despair and depression in the city, especially in the autumn-winter period, significantly reducing physical activity. An analysis of recent research and publications has been conducted to define the term coloristics, to identify the problem of color harmony of cities, to determine the importance of color in architecture and construction, and the impact of different color shades on people. The basis of the purpose of the article was formulated, namely to conduct a visual study and analysis of the situation with the color scheme in Severodonetsk on the example of Prospekt Gvardiysky Avenue which is the central and largest street of this city, which is currently the capital of Luhansk region. The article also made a visual study of the color environment of Gvardiysky Avenue in Severodonetsk, where various problems were identified, and an analysis of the color scheme of this prospectus was given. After considering the current situation with the color scheme on this avenue, current issues were identified and various and current recommendations were proposed to improve the color scheme of the city. It was concluded 
that in Severodonetsk, a due attention is not paid to the appearance of the city and the city streets, even the central ones, are in a rather dilapidated condition. In order to solve the existing problem of harmonization and streamlining the color scheme of Gvardiysky Avenue, it is necessary to create a favorable, harmonious situation in the city to improve the quality of life of citizens. The relevance of the article is that modern problems of general urbanization are beginning to affect the change of the visual environment, which in turn negatively affects the possibilities of human vision and the formation of a comfortable living space.

Key words: coloristic harmony, color, urban environment, integration, color perception. 